\title{
POLITICAL CONSULTATION IN NATO
}

\author{
Dr. Ersin ONULDURAN
}

"There cannot be unity in defence and disunity in foreign policy." These words, uttered approxi nately a quarter of a century ago, by NATO's "three wise men," hold true today, as they did in 1956. What these words allude to, is the very essence of what holds NATO together. This is the practice of political consultation. Political consultation is the most important factor for the continuation and growth of the alliance. Indeed, it is the sine qua non of the alliance which was created to counter imminent threat from outside forces to the territorial integrity and the well-being of its member states.

Political consultation and collective discussion is not merely talking about various policy options; it is the means through which harmonious, and perhaps common, lines of policy can be agreed upon.

Why is political consultation so important? Why is it called, as Sir Clive Rose puts it, "the life-blood of the alliance"?' I think, this can be best explained by likening the NATO alliance to a pioneer family, a family, where parents and grown children must maintain harmony and unity if they are to survive the elements and hostile neighbours. If each member of this family goes his own way and proposes to react in opposing ways to external danger, then the family as a whole, and of course each

${ }^{1}$ Sir Clive Rose, "Political Consultation in the Alliance", NATO Review. Vol. XXXI, No. 1, 1983.

The author gratefully acknowledges the Research Fellowship provided by NATO during the preparation of this article. 
individual member, will fall prey to its enemies. Without consultation in the alliance, it would be very difficult to overcome internal rivalries, lessen tensions and maintain the collective security of the members. Certainly NATO is a partnership of sovereign states and there will be different approaches and reactions in order to cope with internal and external difficulties. However, it is through consultation that options compatible with both sovereignity and partnership can be found, and formulated into policy aciions.

Large states are often accused of acting on international issues without consulting their smaller allies. Although there might be many instances lending credence to this claim, this does not mean that consultation is not looked upon as a desirable course of action by even the superpowers. In 1967 the then vice-president of the U.S., Mr. Hubert H. Humphrey expressed to the Allies the "Golden Rule of Consultation": "...and if we follow the golden rulethat each of us consult as soon, as ofter, and as frankly as he would wish the others to consult- the alliance will prove to be the midwife of more hopeful times."'

Operationally speaking, what categories of interaction between nember states are to be termed political consultation? Opinions of scholars and other writers vary. For example, Harlan Cleveland uses the following categorization : ${ }^{3}$

1. Exchange of information (notification after the fact). This can take various forms e.g. report of NATO ministers' visits to Eastern Bloc countries. Intelligence reports on what has already happened.

2. Analysis. Here various briefings and discussions among experts are included. For example, while the war in Vietnam was going on, the United States gave regular briefings on the progress of the conflict. In addition, na-

2 Quoted in Harlan Cleveland, NATO: The Transatlantic Bargain. New York: Harper and Row, 1970. p. 17.

3 Ibicl., pp. 22-23. 
tional expert assessments on threats to peace are regularly shared among the allies.

3. Consultation about national actions. This consists of notification as a matter of general interest. For example, U.S. base negotiations affecting U.S. forces in Europe, and exchange of views on U.N. annual agenda items fall into this category.

4. Consent building notification (after the fact). The primary example of this is the advance word President Kennedy sent about pending U.S. action in the Cuban Missle Crisis. Also, explanation of the American intervention falls into this category.

5. Advance consultation on national actions. Examples of this category are the U.S.-U.S.S.R. SALT negotiations, Belgian disarmament talks, with Poland, discussion on visits of national leaders to the Soviet Union.

6. Consultation (before and during) with a view to parallel national actions and attitudes. Non-proliferation treaty, periodic Berlin crises, stoppage of contacts with the Warsaw pact members are examples.

7. Consultation (before and during) with a view to colective action. Report On the Future Tasks of the Alliance (1967), Guidelines for the use of tactical nuclear weapons, appointment of NATO commanders, constitute this sort of consultation.

One of the actual participants in many acts of consultation was the Italian diplomat Manlio Brosio. Having served as Secretary -General of NATO from 1964 to 1971, he was in an excellent position to observe the process of consultation first hand. In an article written almost ten years ago $^{4}$ he complained that because a given area falls outside of the geographical boundaries of the Alliance; member nations sometimes tend be reluctant to discuss possible national polities. This reluctance has been lagely remedied in recent years. The Allies have consulted on the MBFR

${ }^{4}$ Manlio Brosio. "Consultation and the Atlantic Alliance". Sur. vival, Vol. XVI, No. 3, op. 115-121. 
negotiations, as well as on the Energy Crisis and, inevitably, on what to do in the event the Middle East oil supply is cut off.

A more recent study is that of Roger Hill. ${ }^{5}$ His book is one of the most definitive works on political consultation. Here we find a detailed survey of the issues upon which political consultation took place up to the mid 1970's. This book also contains an excellent and thorough description of the actual practice and techniques of consultation in NATO.

Another book-lenght treatment of the subject of consultation was done by Maria Rita Saulle. ${ }^{6}$ Professor Saulle reiterates the procedures and suggestions stated in the Three Wise Men's Report and the Harmel Comission Report. She then goes on to examine the various issues which required NATO consultation.

In recent years we have observed an increase in tension and an obvious strain in the relations between the Allies. It would be worth while to focus our attention on a number of issues which create tension in the Alliance and see how consultation can help to reduce these tensions. We will try to accomplis this, first by enumerating the causes of the tension and then by dwelling upon the issues on which the allies see less than eye to eye.

We would like to state at the outset that, although the differences between Europe and American (the two poles of different opinions on various matters) are very real and they have to be dealt with, they are not fatal and "death has not as yet come to the Arch-alliance".? Be that as it may, what are the basic reasons for this trouble? It seems convenient to look at this from two perspectives:

\footnotetext{
${ }^{5}$ Roger Hill, Political Consultation in NATO, Toronto: Canadian Institute of International Affairs, 1978.

6 Maria Rita Saulle, NATO and its Activities, Dobbs Ferry, N.Y.: Oceana Publications, Inc.. 1979.

${ }^{2}$ For a differnet point of view see Earl C. Ravenal, "Death Comes to the Arch-alliance", Inquiry, October 27, 1980, pp. 19-23.
} 
I. First of all there are the psychological reasons. Following World War II, the relations between a developed and untouched by war, America and a devastated and "saved" Europe were ones of codiality and gratitude. What happened to the small nations of the Baltic region and Eastern Europe was a grim reminder to the countries of Western Europet that if they were to remain free, they had to band together and accept the leadership of the United States. Under Stalin's rule the Soviets annexed or otherwise controlled an area amounting to approximately 18000 square miles and over 23000000 population. This expansion took only a few years and had started before the war ended. In addition, by 1948, through pressures and aid to local communist paties, Budapest, Bucharest, Warsaw, Sofia, and Prague all had governments sympathetic to the Soviet Union.

It was obvious that Soviet ambitions would not stop at the borders of the Western European countries. This is why there was an urgent need for the war-torn, democratic nations of Western Europe to join their resources to fend off any possible agression. What followed after this decision was made, i.e. the events leading to the formal establishment of the North Atlantic Treaty Organization are well known and need not be recounted here.

During the post-war years massive American military and economic aid poured into Europe. But this godsent gift also brought with it the seeds of envy. Here was a relatively new country, known in Europe for its innovations in technology, but also for its brash and awkward ways in matters diplomatic, which was shaping the defence planning and economic destiny of the old and mature Europe. This created a complex in the European mind which emerges in different forms even today. For example, one author ${ }^{8}$ suggests that, although formally NATO is a partnership of equals, the presence of over 300000 American soldiers in Europe creates a sense of domination that, the Americans could only understand if 300000 European

${ }^{8}$ Eliot A. Cohen, "The Long Term Crisis of the Alliance", Foreign Affairs, Vol. LXI No. 2, (Winter 1982-1983), pp. 325-343. 
troops were stationed along the Rio Grande separating Mexico and the United States.

As time went by, European perceptions of the Soviet Union changed. Differences began to emerge between the Americans and the Europeans about how to manage the Soviets. A younger generation has emerged which changed the old adage, and began to chant "better red than dead". For this group, the Soviet Union was not quite the agressive giant it was made to be. The benefits of detente partly gave credence to the claims of the "peace movement" adherents.

As détente became an every day word, beriefitis of detente began to become not quite the same thing for Eurcpe and the United States. While détente, of cours: lcssened the tensions between the two super-powers, Americans viewed detente as indivisible. In other words, the Soviet Union could not be permitted to toe the line in Europe, but feel free to cerate mischief in other parts of the world. For the Europeans detente could be divisible. The relaxation of tensions in Europe, and the creation of a military equilibrium (both conventional and nuclear) that the European countries could live with constituted a sufficient benefit for the Europeans.

In a way this is understandable. A report prepared for the U.S. Senate calls the most basic cause of the differences between the two sides of the Atlantic the "we are here and they are there" syndrome. ${ }^{9}$ Here the underlying American assumption is that, since the Europeans are so close to the Soviet Union, they should be very concerned with their safety and thus hold a hard-line attitude. In fact, just the reverse is true. Because of proximity, Europeans know that they will be the major sufferers in the event of a war. Thorefore, they do not wish to become victims of war univittingly. When President Reagan said that he "could sec where you could have the exchange of tactical weapons

: The Congressional Research Service, Crisis in the Atlantic Alliance: Origins and Implications, Washington: U.S. Senate Committee on Foreign Relations, 1982. 
against troops in the field without it bringing either one of the major powers to pushing the button", ${ }^{10}$ the Europeans were aghast with horror, since the "field" mentioned in the statement was in fact their homelands.

Ideology is another intangible cause of rift between the two sides. In America, Marxism is seen as the culmination of all the negative things imaginable. In Europe, on the other hand, while the majority of the people do not wish to live under a Marxist government, this ideology is often a souce of inspiration for social programs or welfare policies. American ideological inconsistencies, political scandals a la Watergate, and on 1again-off-again references to human rights as an end in foreign policy actions, all contribute to dcuks about whether American "ideology" is what it was once thought to be.

Lastly I would like to mention the element of style as one major psychological cause of malaise in the alliance.

The problem of style is a function of how American actions are perceived by the European allies. Here, the issue of prior consultation comes up most urgently. Especially during President Carter's tenure, the Europeans complained of the "zig-zags" in American policy. For example, during the Ford-Carter T.V. debates, President Carter championed a reduction in defense spendings, and yet toward the end of his Presidency a complete about-face had been executed and Americans were again spending money on conventional weapons. President Johnson was not known for his subtlety or elegance in diplomacy. His notorious letter of 1964, written to the prime-minister of Turkey, asking that country not to intervene in Cyprus, has affected the relations between the U.S. and Turkey for almost two decades.

II. As for the issues because of which divergence occurs, the first thing that comes to mind is what NATO is supposed to do for out-of-area theats. Here, of course, the most immediate concern is for the Persian Gulf region. Secondly there is the Indian Ocean security area. In the

10 Ibid., p. 10 . 
Persian Gulf, the U.S. oil imports amount to 10 per cent of the total imorts for that country. The Europeans are much more heavily dependent on oil supply from this part of the world. The general European attitude is to look upon the US-USSR struggle here as one of super power struggle and to not be too bold in pledging support. However, if worse were to happen and the gulf oil was to be cut off on account of Soviet actions, the unified Alliance reaction would be to alleviate the problem by all means necessary. In short, the Europeans do not want to be put in a position of pulling the chestnuts out of the fire for the U.S. As far as we can best determine the main thrust of the European approach here is to provide maximum economic and military support to the countries involved, but to maintain a low profile presence.

The Siberian pipeline issue also caused an uproar of protest within the Alliance when pesident Reagan decided to impose an export ban on all the U.S. manufactured components of the gas pipeline, on October 30, 1981. Six months later, when the ban was extended to include the European subsidiaries of the U.S. componies, the European governments such as Germany and Britain flatly refused to comply. This issue was resolved on November 13, 1982 when the President lifted all restraints. The Americans were known to be rather like-warm about the pipeline anyway. As they saw it, Europe would become dependent on Soviet gas and therefore, could fall under Soviet manipulation. There are convincing counter arguments too. For instance, a number of RAND Corporation studies show that alternative resouces can be marshalled in case of need, and that since the Soviets would need the hard currency earnings from the natural gas sales, they would be inclined to think twice before they attemp a cut-off. ${ }^{.1}$ By $199025 \%$ of the German natural gas would come from the Soviet Union, this would constitute $1 / 4$ of the 16.7 per cent that natural gas occupies in the general energy supply for Germany. For France and

"For a full treatment of this subject see Ed. A. Hewett "The Pipe-line Connection: Issues for the Alliance" The Brookings Review, Fall, 1982, pp. 15-20. 
Italy, $32 \%$ and $35.2 \%$ of the gas supply would be coming from the Soviet Union. In these two countries gas represents $17.2 \%$ (France) and $18.5 \%$ (Italy) of the total energy balance. The total earnings of the Soviet Union by late 1980's would be about seven billion dollars, which very likely will go into the coffers of the U.S., since grain purchases of the Soviet Union from the United States will amount to approximately this much money. ${ }^{12}$

One other issue of great controversy within the Alliance has been the matter of the deployment of intermediate range nuclear forces, INF for short. Several years ago, in 1979. Henry Kissinger gave a spech on the occasion of the thirtieth anniversay of the establishment of NATO, He expressed the need for INF thus "If there is no theater nuclear establishment on the continent of Europe, we are writing the script for selective blackmail in which our allies will be threatened, and in which we will be forced into a decision whereby we can respond only with a strategy that has no military purpose but only the aim of destruction of populations." ${ }^{\prime 13}$

The five countries where intermediate nuclear forces would be employed (Germany, England, Belgium, The Netherlands and Italy) have mixed reactions on this matter. While they all have agreed to the deployment in principle, Eelgium, The Netherlands, England and Germany have vociferous pacifist opposition. All of the European countries would like to see the Americans display a certain ampunt of flexibility at the START negotiations in Geneva. If, for Example, a zero-zero plan, that is, the dismantling of the Soviet SS-20's, SS-4's and SS-5's, in return for not deploying INF weapons, were to be accepted by the parties concerned, all of the European allies would breathe easier.

On other fronts, namely, burden sharing for the cost of maintaining the American forces in Europe, equipment

12 NATO Today: The Alliance in Evolution, Report to the Senate Committee on Foreign Relations. 97th Congress, 2nd Session, April, 1982 , p. 29.

${ }^{13}$ Henry A. Kissinger, "The Future of NATO", Washington Quarterly, Autumn, 1979, p. 8. 
and weapon standardization and economic rivalry between Europe and the United States, there are significant differences to be settled.

Our primary interest is political consultation, one feels certain that the various formal and informal discussion and consultation forums will be used to bring together divergent ponts of view. However, since NATO is a conglomeration of independent, sovereign, democratic states. a certain amount of difference in national policies is inevitable. even desirable. Foreign policy decisions in democratic societies are results of a laborious process of consensus building. Domestic political concerns and sensitivities of the voting public has to be taken into account. In a paper recently delivered, ${ }^{13}$ Gegory Treverton suggests that in the relations with the Eastern bloc, there might be an implicit division of labor, where the Unite States takes the hardline against the Soviet Union, and the Europeans reflect a hint of flexibility. Increasingly, however, this is taken in the American Cogress and other foci of public opinion, as America doing the dirty work while the Europeans "have their Cake, and eat it too". If this feeling reaches serious proportions, and becomes wide spread, the very existence of the Alliance will be jeopadised.

I will close this report by borrowing from the Report of the Committee of Three on Non-military Cooperation:

"Effective and constructive international cooperation requires a resolve to work together for the solution of common problems. There are special ties between NATO members, special incentives and security interests, which should make this task easier than it otherwise would be. But its successful accompilshment will depend largely on the extent to which member governments, in their own policies and actions, take into consideration the interest.s of the alliance. This requires not only the acceptance of

${ }^{14}$ Gregory F. Treverton, 'Is there a 'Crisis' in U.S. - European Relations?", Paper delivered at the conference on "The Successor Generation and the Atlantic Alliance", RAND Corp., Santa Monica, Calif., February 14-17, 1983, p. 21. 
the obligation of consultation and cooperation whenever necessary, but also the development of practices by which the discharge of this obligation becomes a normal part of governmental activity." ${ }^{14}$ There is still a very great truth in these words. They should be taken to heart by the decision-makers and statesmen of all NATO members. Once this is done, then consultation will resolve any "crisis" that exists or is likely to occur in the future.

15 The North Atlantic Treaty Organization, Facts and Figures, Brussels NATO Information Service, 1981, p. 274. 